\title{
INVESTIGATION ON THE DEOXYGENATION RATE OF WATER OF CIMANUK RIVER, INDRAMAYU, INDONESIA
}

\author{
Yonik Meilawati Yustiani*, Sri Wahyuni and M. Ringga Alfian \\ Department of Environmental Engineering, Engineering Faculty, \\ Universitas Pasundan, Indonesia \\ *E-mail : yonik@unpas.ac.id
}

\begin{abstract}
Cimanuk River is one of the biggest rivers that pass through the Indramayu City, West Java, Indonesia. The river is categorized as an urban river and functioned as the main drainage system. Its water quality decreasing due to the urban runoff mixed with the wastewater discharged from the domestic and nondomestic activities. Modeling is one of the management efforts to overcome the water quality problem of the river. Deoxygenation rate becomes important to be obtained in order to have an accurate modeling result. This research was conducted to investigate the deoxygenation rate of the Cimanuk River based on the laboratory analysis and empirical formula calculation. Water samples were taken from 2 points in the Cimanuk River. DO measurement were conducted each day from the incubated samples for 10 days. Slope Method was then being used to determine the deoxygenation rate. The investigation results show that the range of deoxygenation rate of Cimanuk River is 0.06-0.12 per day. The BOD ultimate based on the Slope Method calculation ranges between 23.33 and $34.83 \mathrm{mg} / \mathrm{L}$. Using the empirical equation, the deoxygenation rate was obtained between 0.422 and 0.462 per day. The low value of deoxygenation rate observed by laboratory analysis can be caused by the slow microorganism's activity in decomposing the organic matter due to the unfavorable environment in the water.
\end{abstract}

Keywords: deoxygenation rate, Cimanuk River, Slope Method

@) RASĀYAN. All rights reserved

\section{INTRODUCTION}

Cimanuk is one of the six major rivers in West Java, flowing from the hilly area of Garut City, the Cikurai Mountain, passing through Sumedang and Majalengka areas and ended in the coastal area of Java Sea in the Indramayu City ${ }^{1}$. The rapid increase of city population has resulted in the long-term sustainability of environmental quality ${ }^{2}$. Similar to another urban river in Indonesia, the Cimanuk River received waste from domestic activities. Industrial activities, especially batik, Indonesian traditional pattern textile, production, located near the river will be able to degrade the river water quality by the increment of the accumulation of heavy metal of chromium and to disturb macrozoobenthic population in the river ${ }^{3}$.

Various efforts can be implemented in order to improve the environmental conditions of Cimanuk River. One popular effort to manage and improve the river water quality is the usage of river water quality modeling ${ }^{4}$. Modeling in water quality was developed by Streeter and Phelps in 1925. The model indicates a balance between the increment rate of dissolved oxygen concentration as a result of reaeration process and the dissolved oxygen uptake rate from the decomposition of an organic waste, where the biochemical oxygen demand (BOD) deoxygenation rate was expressed as a first-order reaction, generating the curve of dissolved oxygen sag (DO) model ${ }^{5}$. Therefore, the Streeter-Phelps model is suitable to be used for the river that being contaminated by mainly domestic waste. The deoxygenation rate is one of the primary coefficients in BOD and DO modeling. Determination of specific deoxygenation rates in the study area is important for the accuracy of the modeling results. This coefficient of deoxygenation rate will also illustrate the characteristic of contaminated urban river water. In Indonesia, the river water quality modeling is rarely used in the frame of river improvement ${ }^{6}$. Usage of river water quality model is still not popular due to lack of data and information concerning the characteristic of the urban river water, 
especially in the determination of coefficient values that are used in the model ${ }^{4}$. Generally, river water modeling uses the rate of deoxygenation carbon taken from literature or previous studies ${ }^{7}$. However, the usage of the literature-based coefficient may lead to invalid model. Therefore, the purpose of this research is to study the value of the coefficient of deoxygenation rate of Cimanuk River so that it can be used in modeling the quality of river water both in the process of estimating the quality of river water at present and prediction in the future. The rate constants in the river water quality modeling would give support on predicting the effect of untreated wastewater discharge to biota, the concentration of dissolved oxygen, and concentration of $\mathrm{BOD}^{8}$.

\section{Sampling Locations}

\section{EXPERIMENTAL}

Water samples were taken from 2 points which are considered to be representative of river condition influenced by the Indramayu City activities. The first point which denotes the upstream point, is located the Cimanuk dam outlet at the coordinates of $6^{\circ} 20^{\prime} 14.45^{\prime \prime S}, 108^{\circ} 19^{\prime} 24.91^{\prime \prime} \mathrm{E}$, whereas the second point denotes downstream point is located close to Siliwangi Road at the coordinates of $6^{\circ} 19^{\prime} 35.33$ "S 108 19'16.10 "E. Fig. 1 shows the sampling locations map.

Water samplings were conducted 3 times at each point. Measurements conducted in the field are measurement of river discharge, temperature, $\mathrm{pH}$ and DO. River discharge was determined by several measurements, including river depth, width and flow velocity.

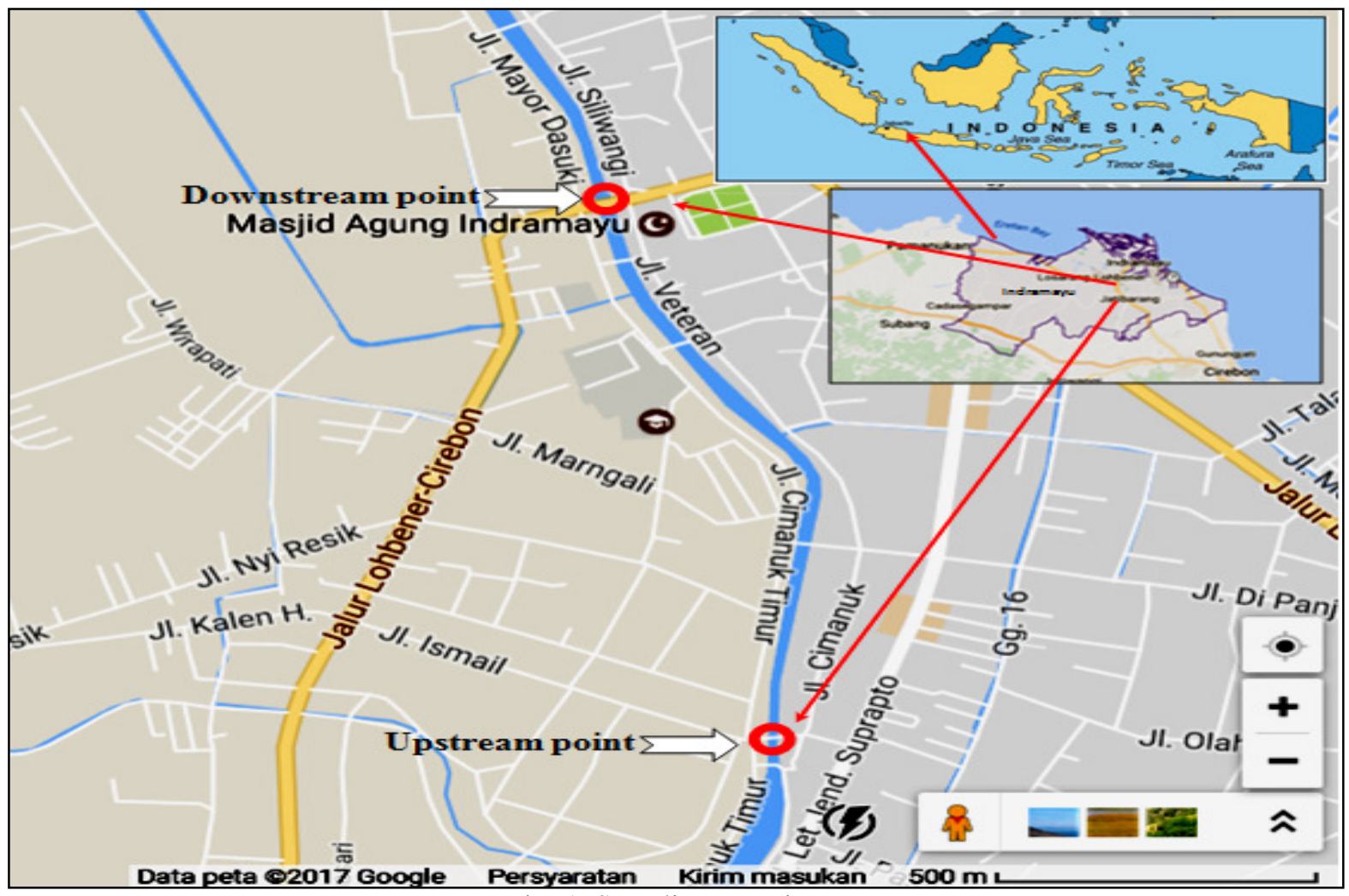

Fig.-1: Sampling Locations.

\section{Determination of Deoxygenation Rate}

The determination of laboratory-based deoxygenation rate was carried out using the daily measurement of DO uptake. Water samples were taken to the laboratory with appropriate procedures and incubated at 20 deg C. The incubation processes use BOD bottles and was carried out for 10 days. DO concentrations were measured daily based on the Winkler modification method ${ }^{9}$. Based on the methods of the USGS (United State Geological Survey), aeration should be conducted when DO reaches a value below $2 \mathrm{mg} / \mathrm{L}$ 
to obtain a significant uptake of oxygen concentration on the next day ${ }^{10}$. To give reliable results, a minimum of 6 days data are usually required ${ }^{11}$. Data acquired from this treatment was calculated using Thomas' method. Thomas' method is considered as the common method in the deoxygenation rate calculation $^{12}$.

Thomas method was introduced by Thomas in 1973. The method is also known as Slope method. It determines the deoxygenation rate based on the similarity of two functions, a graphical analysis using the following function ${ }^{11}$. The calculation gives a constant through least-squares treatment (least squares) to form the basis of the first order reaction equation.

$$
\frac{d y}{d t}=K_{1}\left(L_{a}-y\right)=K_{1} L_{a}-K_{1} y
$$

Where: $d y=$ increase in BOD per unit time

$\mathrm{dt}=$ increase in time

$\mathrm{K}_{1}=$ deoxygenation constant, per day

$\mathrm{La}=$ first stage ultimate BOD, $\mathrm{mg} / \mathrm{L}$

$\mathrm{y}=\mathrm{BOD}$ exerted in time $\mathrm{t}, \mathrm{mg} / \mathrm{L}$

Equation 1 is a linear correlation between dy/dt and $\mathrm{y}$. Consider $\mathrm{y}^{\prime}=\mathrm{dy} / \mathrm{dt}$ as the BOD change rate and $\mathrm{n}$ as the number of BOD measurements minus one. Two equations todetermine $\mathrm{K}_{1}$ and $\mathrm{L}_{\mathrm{a}}$ are presented in Eq.4 and Eq. 5 after solving a and b values in Eq.-2 and Eq.-3.

$$
\begin{aligned}
& \mathrm{na}+\mathrm{b} \sum \mathrm{y}-\Sigma \mathrm{y}=0 \\
& \mathrm{a} \sum \mathrm{y}+\mathrm{b} \sum \mathrm{y}^{2}-\sum \mathrm{yy}^{\prime}=0 \\
& \mathrm{~K}_{1}=\mathrm{b} \\
& \mathrm{L}_{\mathrm{a}}=-\mathrm{a} / \mathrm{b}
\end{aligned}
$$

\section{Empirical Method of Deoxygenation Rate Determination}

Determining the deoxygenation rate using empirical formula was conducted by considering the river depth. The empirical equation was formulated based on experiments to observe a correlation between river depth and the deoxygenation rate. It is initiated by the natural phenomenon that the depth of a river affects the life of the microorganisms in it, where the deeper the depths of a river will give less oxygen content and less number of microorganisms that can live in these waters.

The deoxygenation coefficient used for the calculation of organic water pollution model is used as formula according to Hydroscience $(1971)^{13}$ for normal flow. The deoxygenation rate was obtained from Hydroscience empirical equation which is using the physical condition of the river, its water depth.

$$
\mathrm{K}_{\mathrm{d}}=0.3 \times\left(\frac{\mathrm{H}}{8}\right)^{-0.434}
$$

Where: $\mathrm{K}_{\mathrm{d}}=$ deoxygenation rate (per day), $\mathrm{H}=$ water depth (ft).

\section{Onsite Measurement}

\section{RESULTS AND DISCUSSION}

Based on the observation result, the Cimanuk River discharge ranges between 1.45 to $1.86 \mathrm{~m}^{3} / \mathrm{s}$, while the river depth in the upstream is slightly deeper $(1.11 \mathrm{~m})$ than that in the downstream point $(0.90 \mathrm{~m})$. The shallow river will enhance the aerobic degradation process of organic matter. Therefore, shallow water depth should give a high rate of deoxygenation and aeration ${ }^{14}$.

The onsite measurement gives data shown in Table-1. The DO concentrations in the upstream point range around $8 \mathrm{mg} / \mathrm{L}$, whereas in the downstream point range around $7.5 \mathrm{mg} / \mathrm{L}$.

The DO concentrations appear in quite high range. The aerobic degradation of organic matter will more likely be carried out in the river with a high concentration of DO. However, the degradation would be taken place in the presence of microorganisms. The $\mathrm{pH}$ values are also in a neutral condition which is 
favorable for degradation process. Aquatic biota may live optimally in this range of $\mathrm{pH}$. Indramayu City is located in the north coastal area of Java Island. It has a relatively high temperature of atmosphere that influences the warmth of Cimanuk River water.

Table-1: DO, $\mathrm{pH}$ and Temperature of Cimanuk River

\begin{tabular}{c|c|c|c}
\hline \multirow{2}{*}{ Sampling point } & \multicolumn{3}{|c}{ Parameter } \\
\cline { 2 - 4 } & $\mathrm{DO}(\mathrm{mg} / \mathrm{L})$ & $\mathrm{pH}$ & Temperature \\
\hline Upstream 1 & 8.8 & 7.48 & 31.2 \\
\hline Upstream 2 & 8.2 & 7.5 & 30.5 \\
\hline Upstream 3 & 8.1 & 7.51 & 31.8 \\
\hline Downstream 1 & 7.5 & 7.5 & 31.1 \\
\hline Downstream 2 & 7.6 & 7.23 & 31.2 \\
\hline Downstream 3 & 7.3 & 7.5 & 31.2 \\
\hline
\end{tabular}

\section{Laboratory-based Deoxygenation Rate}

Figure-2 shows the graph of daily accumulation of DO loss of the upstream water samples. DO loss is the decrease of DO concentration due to uptake by microorganisms. The highest DO loss observed was approximately $17 \mathrm{mg} / \mathrm{L}$, whereas the lowest was $13 \mathrm{mg} / \mathrm{L}$. Considering high concentration of initial DO concentration, those accumulated DO loss in the upstream water sample appears low. During the initial phase of the BOD process, the substrate is assimilated by bacteria under aerobic conditions and a major portion of the substrate is converted to biomass ${ }^{15}$. The Thomas' Slope method gave deoxygenation rate value of the upstream Cimanuk River water ranged from 0.10 to 0.12 per day.

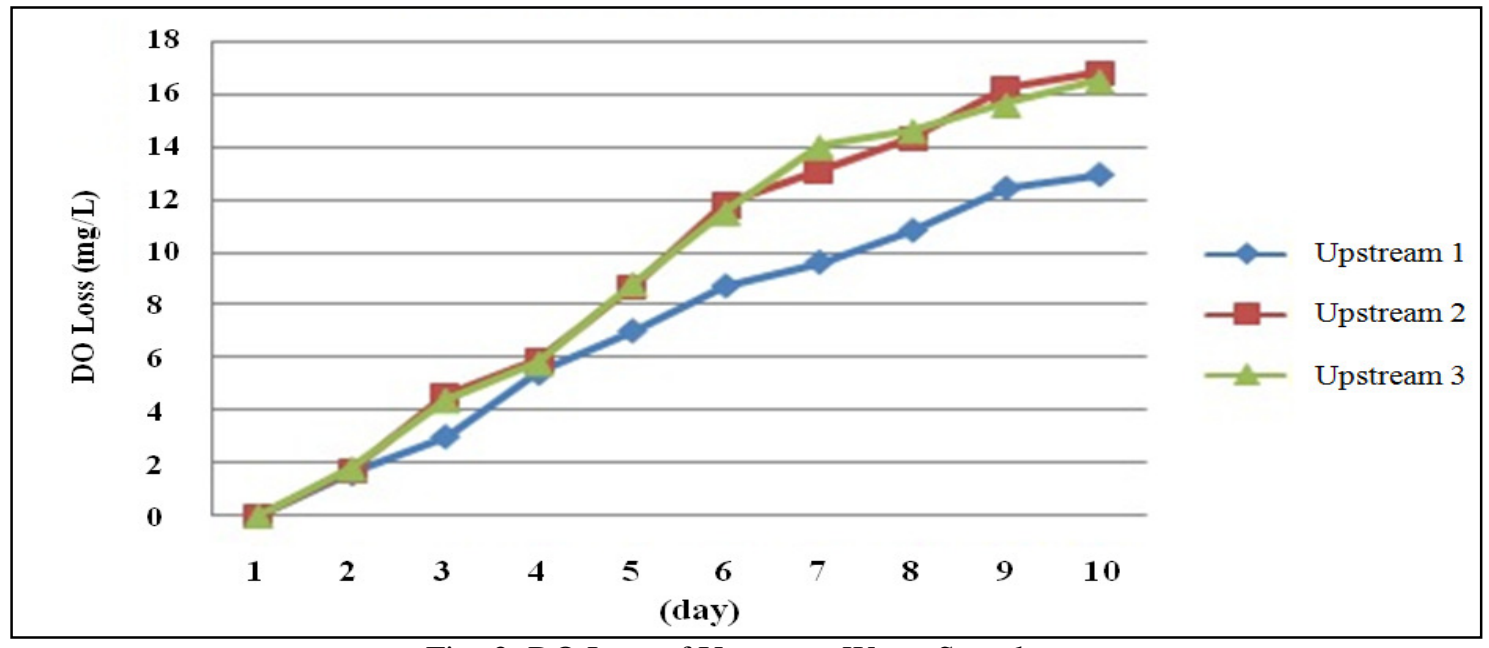

Fig.-2: DO Loss of Upstream Water Samples.

Figure-3 depicts the graph of accumulation of DO loss of the Cimanuk River downstream water sample. At the last day, the concentration of DO loss accumulation is $16-18 \mathrm{mg} / \mathrm{L}$. The range is slightly higher than that of the upstream water sample. The result of the deoxygenation rate calculation gives the range of 0.06 to 0.08 per day.

A typical value of the deoxygenation rate for the surface water is $0.10-0.23$ per day ${ }^{16}$. The upstream water result is suitable for the typical condition of deoxygenation rate. The deoxygenation rate range in the downstream water of Cimanuk River shows lower than that in upstream water. The low rate of deoxygenation is usually observed in cleaner water. However, the condition of slow rate may be caused by insufficient decomposer microorganisms. Deoxygenation values upstream and downstream show 
different activities of microorganisms present in the use of oxygen in degrading different organic substances. The main process that reduces the dissolved oxygen concentration of water is the oxygen uptake by aquatic microorganisms in decomposing biodegradable organic matter ${ }^{17}$. Lower deoxygenation rates were also indicated in other urban rivers in Indonesia ${ }^{4,14}$.

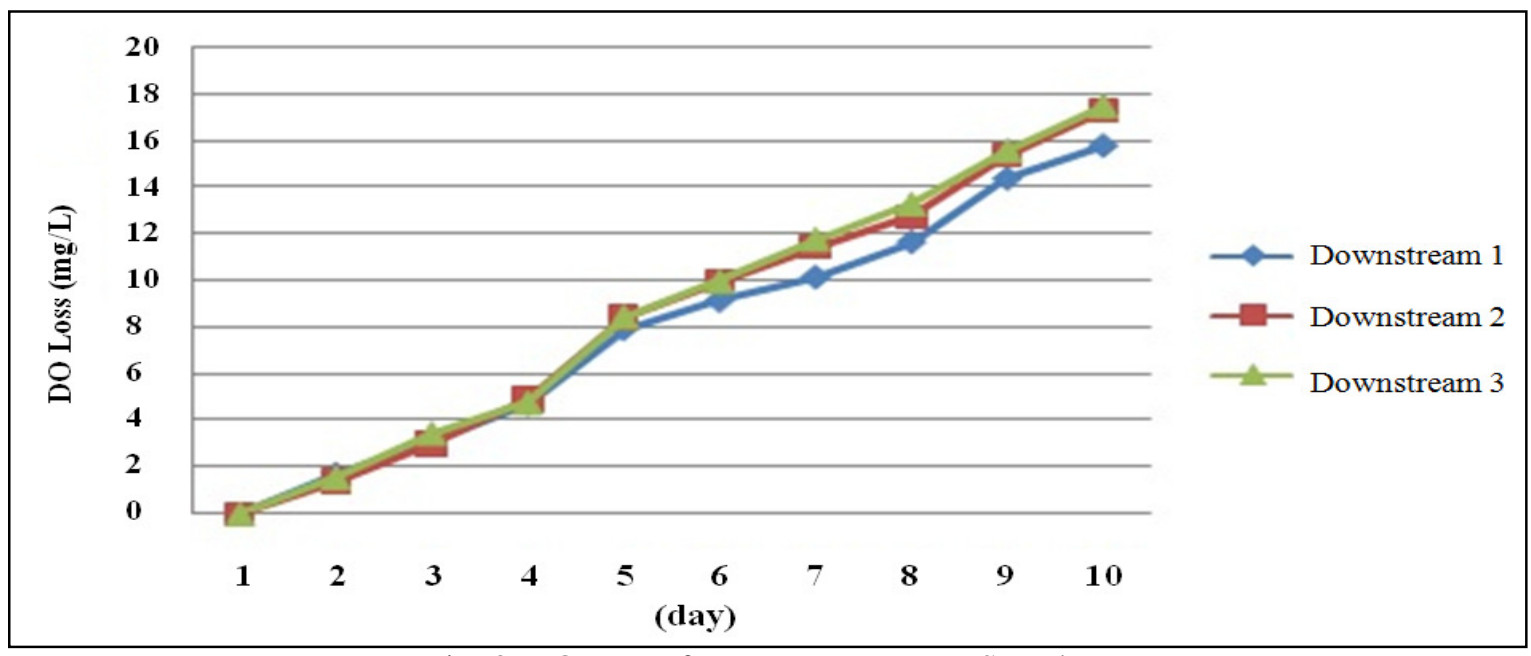

\section{Ultimate BOD}

Fig.-3: DO Loss of Downstream Water Samples.

Ultimate BOD is the concentration of oxygen needed to completely degrade organic matter. In the modeling of water quality, the biodegradable organic matter is taken into consideration by the biochemical oxygen demand (BOD) parameter, which is shown as the unit mass of oxygen uptake from a unit volume of water by microorganisms during a specified period of time ${ }^{17}$.

In this research, the ultimate BOD value was obtained using laboratory analysis on each sample and calculated using the Slope method. Table-2 shows the ultimate BOD concentration of water samples. The results indicate that BOD concentrations in the upstream part are lower than those in downstream of Cimanuk River. A typical concentration of BOD range of surface water is between 1 and $30 \mathrm{mg} / \mathrm{L}$. Higher concentration of BOD in the stream can be caused by the contamination from the surrounding activities' wastewater. Strong municipal wastewater may have BOD as high as $250 \mathrm{mg} / \mathrm{L}$.

Usually, high BOD will stimulate higher deoxygenation rate, especially when DO concentration is sufficient. However, the observed deoxygenation of Cimanuk River gives a slow rate. This condition may be affected by an atoxic or chemical compound that inhibits the degradation process of microorganisms in the river.

\section{Empirical Determination of Deoxygenation Rate}

The deoxygenation rate can be more easily determined by using empirical equations proposed by Hydroscience ${ }^{13}$. Table-3 presents the result of deoxygenation rate based on the empirical equation.

Table-2: Ultimate BOD of Water Samples.

\begin{tabular}{c|c}
\hline Sampling point & Ultimate BOD $(\mathrm{mg} / \mathrm{L})$ \\
\hline Upstream 1 & 23.32 \\
\hline Upstream 2 & 23.73 \\
\hline Upstream 3 & 24.25 \\
\hline Downstream 1 & 34.83 \\
\hline Downstream 2 & 32.00 \\
\hline Downstream 3 & 38.50 \\
\hline
\end{tabular}


Table-3: Empirical Determination of Deoxygenation Rate

\begin{tabular}{c|c|c|c}
\hline \multirow{2}{*}{ Sampling point } & \multicolumn{2}{|c|}{ River Depth } & \multirow{2}{*}{$\begin{array}{c}\text { Empirical } \\
\text { Deoxygenation } \\
\text { Rate (per day) }\end{array}$} \\
\cline { 2 - 3 } & Meter & Feet & 0.422 \\
\hline Upstream & 1.1 & 3.64 & 0.462 \\
\hline Downstream & 0.9 & 2.95 & 0.95 \\
\hline
\end{tabular}

The deoxygenation rate range with the empirical formula is 0.422 to 0.462 per day. Compare to the laboratory-based constants, these empirical-based rates are relatively high for the surface water type. The rate of deoxygenation at the sampling site for the downstream point is greater than the rate of deoxygenation at the sampling site for the upstream point. It is possible because the depth of the sampling site for the downstream point is shallower than the depth at the sampling site for the upstream point, because the depth of the river affects the life of the microorganisms in it, where the deeper the depth of a river the less oxygen content and less the number of microorganisms present in the water is also less deoxygenation rate in a river.

\section{CONCLUSION}

The result of deoxygenation rate range observed from the laboratory analysis of Cimanuk River water is 0.06 to 0.12 per day and ultimate BOD value is $23.32 \mathrm{mg} / \mathrm{L}$ up to $34.83 \mathrm{mg} / \mathrm{L}$. Using calculation with the empirical formula, resulting in deoxygenation rate of 0.422 to 0.462 per day. From the above results the deoxygenation rate range by using laboratory analysis is much lower than the value of the deoxygenation rate range using the empirical formula in the upstream point. The low rate of deoxygenation was also found in other urban rivers in Indonesia. The condition might be occurred by the unpleasant condition of water for microorganisms to live and decompose the organic matter. Ultimate BOD concentration range shows that the amount of organic matter contained in Cimanuk River water is relatively high, i.e. 23.32$34.83 \mathrm{mg} / \mathrm{L}$. The concentration of BOD both in the upstream and downstream are higher than the stream standard. The condition occurred because the Cimanuk River flows through residential areas which mostly contain organic waste that will increase the use of oxygen by microorganisms to degrade the organic substances. The observed deoxygenation process of Cimanuk River water gives slower rate than that of typical surface water. This condition may be affected by an atoxic or chemical compound that inhibits the degradation process of microorganisms in the river.

\section{REFERENCES}

1. S.B. Susilo, D.S. Sjafei, Jurnal Ilmu-ilmu Perairan dan Perikanan Indonesia, 13, 1(2006)

2. R. Arora, H.C. Joshi, I. P. Pandey, V.K. Tewari, Rasayan J. Chem., 10(4), 1167(2017) DOI: 10.7324/RJC.2017.1041753

3. A.M. Gitarama, M. Krisanti, D.R. Agungpriyono, Jurnal Ilmu Pertanian Indonesia (JIPI), 21, 1 (2016)

4. Y.M. Yustiani, Pollution Research, 35, 3(2016)

5. T.N.T.K. Nawarathana, M. Makehelwala, International Journal of Scientific and Research Publication, 6, 4(2016)

6. Y. M. Yustiani, L. Lidya, Procedia Engineering, 154, 353(2016), DOI: 10.1016/j.proeng.2016.07.490

7. E. Hendriarianti, N. Karnaningroem, Journal Applied Environmental and Biological Science, 5, 12 (2015)

8. S.G. Kalamkar, R.K. Raiand S.M. Shinde, Proceedings of 3 IRF International Conference, Goa, India, 126 (2014)

9. APHA/ AWWA, Standar Methods for Examination of Water and Wastewater, 22nd Edition, APHA, Washington DC, USA (1995)

10. J.P. Stamer, J.P. Bennetts, S.W. McKenzie, Determination of Ultimate Carbonaceous BOD and the Specific Rate Constants, USGS Open-file Report: 82-645 (1983) 
11. S.D. Lin. Water and Wastewater Calculations Manual. Second edition. McGraw-Hill. 10 (2007)

12. I. Adewumi, I.A. Oke, P.A. Bamgboye, Journal of Applied Sciences, 5, 1 (2005)

13. Hydroscience, Inc. Simplified Mathematical Modeling of Water Quality, prepared for the Mitre Corporation and the USEPA, Water Programs, Washington, D .C. (1971)

14. Y.M. Yustiani, L. Mulyatna, F. Pranata, AIP Conference Proceedings, 1554, 281 (2013)

15. B. Singh,Master Thesis, Department of Biotechnology and Environmental Sciences, Thapar Institute of Engineering and Technology, Patiala, India (2004)

16. H.S. Peavy, D.R. Rowe, G. Tchobanoglous, Environmental Engineering. McGraw Hill, New York, $43(1985)$

17. R. Jha, C.S.P. Ojha, K.K.S. Bhatia, Hydrological Sciences-Journal-des Sciences Hydrologiques, 52 , 2 (2007)

[RJC-1892/2017] 